\title{
Timacum Minus in Moesia Superior-Centrality and Urbanism at a Roman Mining Settlement
}

\section{Lina Diers}

Institute for Classical Archaeology, University of Vienna, Franz-Klein-Gasse 1, 1190 Vienna, Austria; a01277655@unet.univie.ac.at

Received: 16 September 2018; Accepted: 19 October 2018; Published: 22 October 2018

\begin{abstract}
When applying traditional criteria of Roman urbanism, several settlements in the province of Moesia are not recognised as parts of the urban network. To avoid this, previous criteria of urbanism should be revised. This paper suggests revisions, which provide a more inclusive definition of urbanism: Thus, instead of focusing on administrative status and monumentality as primary markers of urbanity and urbanization, development factors for agglomeration and centrality are emphasized as decisive conditions for, and characteristics of, urban settlement. To provide a case study for this theoretical outline, the upper-Moesian mining settlement of Timacum Minus is evaluated by ideas derived from a critical appreciation of Walter Christaller's central place theory. Timacum Minus did not have official settlement status and monumental character, yet, it developed as a central place in the unique landscape of the Timok valley. This was due to its location as a central road station, military post, and settlement along the important interregional Timok valley road as well as the site hierarchy as the base of the centralized administration of the Timok valley mining district. Hence, Timacum Minus displays different levels of centrality. Interestingly, the site only held these properties during the Roman Principate, although its central location and mining activities also existed in pre-Roman and post-Roman times. This demonstrates the significance of centrality mechanisms as determined by local and regional circumstances and historical conditions. Accordingly, it is argued that these circumstances and the diverse character as a central place also turned Timacum Minus into an urban site, irrespective of status and monumentality. This definition of the site provides not only an example of how to use central place theory in current archaeological thought but also possibilities for re-thinking urbanism in Roman Moesia.
\end{abstract}

Keywords: Timacum Minus; Moesia Superior; central place theory; centrality; Roman urbanism; settlement status; Roman mining

\section{Introduction-Central Place Theory and Roman Urbanism}

When Walter Christaller first introduced his 'central place theory', he stated that centrality patterns were logical and organic and, thus, immanent to principles of settlement development [1] (pp. 21, 25). Accordingly, a central place for Christaller was a town. He even went as far as stating that the main 'profession' of a town was merely to be central to its environment, both in terms of the geometry of location and regional hierarchy [1] (p. 23). With this conclusion, Christaller made a clear statement, which was followed by many scholars concerned with settlement patterns in archaeology [2-6]. Yet, since the 1930s common consensus shifted to believe that central place theory is not as static as suggested and also does not solely relate to urban settlements. Instead, a wide variety of site types that held central properties of any kind and contributed to political, economic, and social networks have been referred to as central places $[3,5,6]$. Clearly, this is a desirable development within archaeological thought. Yet, to build critically on the ideas derived from central place theory, interpretations need to be able to differentiate urban from non-urban sites. 
In Roman Archaeology, however, the outline of urban criteria is no easy task. During the past 150 years, the discipline has struggled to come to a coherent conclusion about urbanity. Problematically, the approach to Roman urbanism has primarily been guided by ideological perceptions. Accordingly, the Roman town has not only been viewed as a manifestation of Roman imperialism and implementation of power and political strategies in the provinces, it has also been perceived as both the primordial and constant of Roman culture. Based on the works of Republican and Principate-times Roman authors, urban settlements in the provinces have, since the 19th century, been addressed as "small likenesses" of Rome [7] (p. 41), as an ideal translation of urban form and, thus, implementation of Roman imperial ideology [7-9]. This idealistic conception has resulted in a paradox situation: Throughout the Roman Empire a Roman town has been identified as such if it was officially installed as a manifestation of Roman, ideological and imperial power in the provinces and resembled Rome in terms of architectural markers, which conveyed the meaning of this manifestation. This concept nicely fitted 19th century conceptions of imperialism and cultural primacy, however, 19th century Zeitgeist also initiated discussions in contemporary urbanism, where Rome was perceived as the formal and moral pitfall of urban development, as a metropolitan dystopia, which needed to be avoided in favor of well-planned and functional towns. Here, the Roman towns in the provinces were used as ideal examples for such urban implementations [10,11]. The paradox of these 19th century opposite arguments quickly settled in archaeological thought and have persisted ever since. Although the debate of the past two decades has long acknowledged that Empire-wide patterns of idealistic implementations of urbanism are a myth [12], the theoretical vacuum of Roman urbanism has not yet been successfully filled and traditional approaches to urban character in the provinces' settlements remain predominant today. These approaches primarily focus on the official status of settlements as coloniae or municipia, which relates to their independent administration, and their monumentality both in size and architectural equipment with certain building types, which relates to urbanization and urbanization rates. What criteria a Roman town needed to fulfil in order to be perceived as a Roman town has been more contingent upon ideological perceptions of urbanism, politics, and culture than upon local and regional circumstances for its development $[7,8]$. This becomes clear when looking at a most recent example: In his empire-wide and generally brilliant study of Roman urbanism, John Hanson has recently shown that there is not necessarily a direct relationship between status granting, settlement size, and the presence and number of monuments. This alone should make a point for the need to reassess the characterization criteria for urban sites. Yet, Hanson still states that urbanism was rather "made up by a small number of important sites than by larger numbers of unimportant sites" [13] (p. 94), and in his catalogue of urban sites of the Roman Empire, he correspondingly, for example, does not include Timacum Minus. I, however, argue that before implying categorical patterns and characterizations of Roman urbanism based on idealistic perceptions of urban form and imperial agendas, one needs to define what 'important' and 'unimportant' mean and that this relates to local and regional levels.

\section{Urbanism in Moesia-Settlement Classification between Paradigm and Paradox}

The need for a reassessment of definitions of urbanism per se and its characteristics is exemplified very clearly by the Roman province of Moesia. Moesia was installed as a province sometime between $\mathrm{AD} 15$ and 45 and divided into Moesia Superior and Inferior during the reign of Domitian. To date, these two province parts/provinces have always been investigated separately, although they display very similar settlement patterns and settlement development factors. When compared to other regions of the Roman Empire, Moesia has frequently been referred to as being little urbanized in terms of both the number of settlements and their monumentality [14-16] (p. 255). This perception, however, mostly derives from the criteria of traditional approaches to urbanism. When, for example, applying the traditional urban marker of administrative status to Moesia, the province had 15 newly installed Roman settlements with official status (Figure 1; Table 1). This, indeed, does not appear to be a pattern of dense urbanism. Yet, when taking a closer look at Moesian settlements, seven sites with considerable 
local and regional significance fall out of the urban pattern, as they did not have official status as a colonia, a municipium or the like (Figure 1: nos. 5, 6, 8, 12, 16, 18, 19; Table 1). These sites are commonly referred to as 'quasi-urban' settlements [14,16], [17] (pp. 68-70), [18] (pp. 211-217). I argue that this is no adequate terminology, and that before implementing a hierarchy of urban, quasi-urban, and non-urban sites, one should consider re-defining urban criteria. Mapping urban settlement in Moesia without the seven settlements outside the status-pattern impairs the determination of settlement networks and urban evolution. Accordingly, it can be useful to find a way of settlement classification for Moesia, which includes these sites instead of marginalizing them. Hence, I use a different approach to urbanism and urban criteria: Instead of classic markers of administrative status and monumental building, I focus on locally and regionally defined development factors for agglomeration [19]. In the case of Moesia, these factors are long-term military presence, imperial foundation acts, and mining activities (Figure 1; Table 1).



Figure 1. Overview of urban settlements in Moesia (Superior and Inferior), including the Pentapolis at the western Black Sea littoral. (C) Raffaela Woller, Lina Diers.

Table 1. Classification of Moesian urban settlements by significant local and/or regional development factors (military presence, imperial agency, mining) instead of administrative status. Administrative status of respective settlements for comparison is indicated in parentheses.

\begin{tabular}{ccc}
\hline $\begin{array}{c}\text { Military Garrisons with Civilian } \\
\text { Settlement (Legionary, } \\
\text { Auxiliary) }\end{array}$ & $\begin{array}{c}\text { Imperial Foundations (Coloniae, } \\
\text { Municipia, Others) }\end{array}$ & $\begin{array}{c}\text { Mining Settlements (with or } \\
\text { without Military Presence) }\end{array}$ \\
\hline Viminacium (3) (municipium) & & \\
Singidunum (1) (municipium) & & \\
Margum (2) (municipium) & & \\
Horreum Margi (4) (municipium) & & TIMACUM MINUS (5) \\
Naissus (7) (municipium) & Scupi (10) (colonia) & Ulpiana (9) (municipium) \\
Novae (14) (municipium) & Oescus (13) (colonia) & Municipium DD (8) \\
Durostorum (17) (municipium) & Montana (12) \\
Troesmis (21) (municipium) & Ratiaria (11) (colonia) & Remesiana (6) \\
Noviodunum (22) (municipium) & Nicopolis ad Istrum (15) & \\
Sexaginta Prista (16) & Marcianopolis (19) & \\
Abritus (18) & Tropaeum Traiani (20) & municipium) \\
& &
\end{tabular}


In focusing on these development factors, I, of course, have no intention to devalue administrative status as a significant aspect of urban development. In fact, there is no question that a Roman colonia or municipium also was an urban settlement. There should, however, also be no question that a settlement without administrative status might just as likely have been urban due to the significance it gained through its development factors or its role in inter-settlement communication networks. Granting administrative status to settlements had only been a single event in a settlement's history, which, in the case of Moesia, often only happened after the respective settlement had already existed for several generations and had developed an economic and social environment suitable for urban growth and urbanization. Moreover, there were diverse reasons for an official granting of administrative status to a settlement, which were clearly guided by both global and local circumstances and agendas. The development factors for settlement and agglomeration as defined above, however, were clearly factors that promoted the significance of settlements irrespective of their status and that made them, in some way, central, not only as a point of attraction to their direct environment but also in terms of regional networks. Hence, I define urbanity as a dynamic mixture of social practice [20] and centrality, and argue that urbanity does not necessarily equal urbanization [21]. In contrast, there had clearly been different levels and scales of urbanization in Moesia that not necessarily decided which sites were urban. This was, in fact, done by the decisive development factors of military presence, special imperial beneficence, and mining, which made settlements socially and economically attractive and, thus, central. Hence, in Moesia urbanism is very much linked to centrality as an integral part of urbanity and a major factor for urbanization. Accordingly, I argue that brainstorming Christaller's central place theory may help to define urban settlement in Moesia, and I shall demonstrate this by discussing the site of Timacum Minus, which was one of the settlements of Moesia without administrative status.

\section{Timacum Minus}

\subsection{The Geography and History of Timacum Minus}

Timacum Minus lay in the hinterland of the Danube Limes amidst the valley of the Timok river in today's north-eastern part of Serbia (Figure 1: no. 5). The Timok valley was one of the earliest, 1st century AD lines of Roman approach from Macedonia, which at that point was already institutionalized as provincial territory, into Moesia and towards the Danube [22]. In fact, the river valley provided the only direct route from the south west of the Stara Planina to the Danube east of the Iron Gates. As the Iron Gates were only made passable for river transport during the reign of Trajan, this route was clearly significant for military and general transport purposes during the 1st century AD. Accordingly, an interregional road passing the Timok valley had already been installed during the 1st century AD to serve military and transport purposes [23], [24] (pp. 7-23), [25] (pp. 97-118). Eastern Serbia is generally characterized by mountainous and inaccessible terrain. The area towards the modern Serbian-Bulgarian border, which is marked by the Timok valley, is enclosed by the western foothills of the Stara Planina to the east and the Homoljska Planina to the west. Bordered by these mountain ranges, the Timok river had various tributaries, which defined the landscape of the Timok valley. Accordingly, the Timok comprises the Trgoviški Timok, the Svrljiški Timok, the Beli Timok, the Crni Timok, and the Veliki Timok. The Trgoviški Timok, which originates in the western foothills of the Stara Planina, and the Svrljiški Timok, which starts north of the village of Prekonoga near Svrljig, meet in Knjaževac some $10 \mathrm{~km}$ south of the site of Timacum Minus to form the Beli Timok. At Timacum Minus, the terrain opens up towards the east, which in Roman times provided the possibility to lead the Timok valley road eastwards towards the Danube settlement of Ratiaria near today's Vidin in Bulgaria. From Timacum Minus, however, the Beli Timok continues north towards the modern town of Zaječar, where it meets the Crni Timok, which origniates near Krivi Vir about 30 km east of the Morava. From this confluence of Beli and Crni Timok, the river continues as the Veliki Timok to eventually flow into the Danube between the Iron Gates and Ratiaria. This extraordinary fluvial landscape offered great connective potential. The Timok tributaries opened the enclosed Timok valley in different directions. 
First, the connection of the Crni Timok to the west provided a link to the Morava, which was the major north-south fluvial traffic axis of Moesia Superior during the Principate. The levelled terrain at the confluence of the Trgoviški and Svrljiški Timok and at Timacum Minus provided connections to Ratiaria and further along the Danube Limes road east of the Iron Gates and to Thracian Serdica via Montana at today's Mihajlovgrad/Montana. Apart from the fluvial network, the road through the Timok valley clearly was of great significance, as it connected Naissus at the southern end of the Timok valley with Ratiaria and, thus, the Adriatic with the Danube. This allowed for the creation of a dynamic, interconnected traffic network, whose various lines of communication coalesced in Timacum Minus (Figure 2).



Figure 2. The Beli Timok at Timacum Minus (photo by L. Diers).

Due to these extraordinary locational properties, the site of Timacum Minus was already occupied during the 1st century AD. Here, legio V Macedonica and IV Scythica presumably erected temporary camps at Timacum Minus on their way to the Danube [22], [26] (p. 51), [27] (pp. 142-144). During the reign of Vespasian, however, military presence in Timacum Minus became more permanent: A road station was installed along the Naissus-Ratiaria military road through the Timok valley, and it was accompanied by a small auxiliary fort of cohors I Thracum Syriaca [28] (pp. 44, 88-90). To facilitate traffic along the Timok valley road, two further road stations developed at this time and they were situated at Timacum Maius near today's village of Niševac and Conbustica at modern Kladorup [25] (pp. 97-118). Given the location of these road stations and their distance from one another, the route from Naissus to Ratiaria could have been travelled in several, convenient day-trips. After this initial occupational phase, Timacum Minus developed further in the 2nd century AD. The vast mountain ranges that enclose the Timok valley from all sides held rich mineral deposits, which made the region even more appealing to the Roman state. From Trajanic times onwards, a large fiscal mining district developed around Timacum Minus and throughout the 2nd century AD [29-31], [32] (p. 197), [33] (p. 31), [34,35], the exploitation of mineral resources gradually increased its economic potential. This also had effects on Timacum Minus. During the reign of Marcus Aurelius, the newly founded cohors II Aurelia Dardanorum was transferred to Timacum Minus and replaced cohors I Thracum Syriaca [16] 
(pp. 123, 170), [28] (pp. 44-45, 66-67, 73-77, 82-85), [36] (p. 514). This coincided with the initial erection of a first, permanent stone-built auxiliary camp. Both the shift of military units and the erection of a stone camp in Timacum Minus were aimed at the protection and maintanence of the Timok valley road, the newly opened mines in the surroundings, and the road and river transport of mining commodities. In both contextual and spatial relation to the auxiliary camp, a civilian settlement developed at Timacum Minus. To date, it has not become clear whether this settlement already existed in the 1st century AD or only developed after the onset of mining in the vicinity and the deployment of cohors II Aurelia Dardanorum. What is clear, however, is that due to the traffic significance of the site and the mining industry in its hinterland, both the military camp and the civilian settlement of Timacum Minus remained occupied throughout the Principate, the late Roman period, and up until the early 6th century AD [36] (p. 518).

\subsection{Roman Mining in the Timok Valley}

The mountains towering to both west and east of the Timok valley from its beginning at Trgovište to Timacum Minus and further north formed an enclosed mining landscape from the beginning or middle of the 2nd century AD onwards [29-31], [32] (p. 197), [33] (p. 31), [34,35]. Especially in the Svrljiška and southern Homoljska Planina to the west of the Timok valley and on the western fringes of the Stara Planina to its east, Roman mining activity has been detected at several sites. Judging from these sites and their distribution, the areas east and southeast of Timacum Minus appear to have been the center of the mining district. Here, various archaeological surveys revealed scattered finds of slags, tools, and structures for ore processing. Such finds have, for example, been made near the modern villages of Aldinac, Repušnica, Gradište, Žukovac, Kalna, Donja Kamenica, Balta Berilovac, Pričevac, Staro Korito, and Dejanovac. To the west of Timacum Minus, towards the Rtanj and Ozren mountains north of the Timok valley, the same types of finds have been encountered at the sites of Bukova Glava, Crni Vrh, Bučje, Dobro Polje, Ilino, Boljevac, Valakonje, and Orešac [28] (p. 20), [32] (pp. 195-196), [37] (pp. 127, 130), [38] (p 192), [39] (pp. 55-56, 77, 82-83, 85, 165, 177, 185, 203, 217). Some of these sites did not only reveal evidence of ore processing but also protective installations like small fortifications or watchtowers (e.g., in Gradište, Dejanovac, Orešac), which safeguarded both the mines and the transport of their commodities [32] (p. 200), [39] (pp. 85, 165). Yet, all sites related to mining in the Timok valley were only identified by basic terrain surveys. The mines, the associated facilities and buildings, and the finds scattered on-site have not been published in detail to date. Large-scale archaeometric analyses of the slag finds have also not yet been conducted. Accordingly, the archaeological evidence for mining is of fragmentary nature and an exact dating of single mining sites in the Timok valley is not possible at the current state of research. Accordingly, it has also not yet become explicitly clear how exactly the mining activities in the Timok valley may be put in a chronological order.

Despite this problem, there is no doubt that the mining activities in and around the Timok valley had a close relationship with Timacum Minus. In fact, several inscriptions found around the site, which name administrative offices related to a centralized organization of the mining, demonstrate that the mining in the Timok valley was controlled from Timacum Minus. The most crucial of these inscriptions surely is IMS III/2,31, as it names both an active soldier who also served as a librarius for mining matters in Timacum Minus and the office of a praefectus territorii, which clearly also refers to mining [28] (pp. 83-84). Thus, the inscription not only confirms entangled military and civilian involvement in mining business but also hints at the existence of a delineated, probably fiscal mining territory, which stood under the supervision of a praefectus who operated from Timacum Minus. Although the epigraphic and archaeological evidence from the Timok valley and its surroundings has by far not been able to identify the exact extent and administrative character of this mining territory, it is clear that Timacum Minus played a central role in all organizational matters of the regional, imperial economic ventures. 


\subsection{The Settlement of Timacum Minus—Archaeological and Epigraphic Evidence}

The site of Timacum Minus comprises the military camp of cohors I Thracum Syriaca and cohors II Aurelia Dardanorum, a civilian settlement around this military camp, the necropolises of both settlement spaces, and several features in the direct hinterland of the site (Figure 3). The area of the camp, the civilian settlement, and the necropolises lie in flat terrain, which slopes gradually towards the surrounding mountains, for example, the hills of Slog and Podina, in the west, northwest, and southwest. To the east and north, the site is bordered by the course of the Beli Timok, which makes a turn at the northern end of the site to enclose the settlement space of Timacum Minus. To the northwest of the camp, the settlement and necropolis area is cut by a small river, the Ropinski brook. The overall settlement area, which is enclosed by these landscape markers, today lies on privately owned farmland, which stretches to the west towards the surrounding hills and mountains and to the south towards the fringes of the modern village of Ravna. Both the private ownership of the settlement area and its extensive agricultural use have complicated archaeological research onsite in the past decades. Accordingly, the only preserved feature of the site of Timacum Minus is the military camp, which is still visible in the terrain today and has partially been conserved.

The earliest military camp of Timacum Minus, which was related to the garrison of cohors I Thracum Syriaca during the reign of Vespasian, was a timber construction. It has only been partially identified by small sections of palisades supported by square timber towers in the area of the camp's western gate. In addition, a defensive ditch dating from the mid-/late 1st century AD was located along the camp's eastern side [28,36,40], [39] (p. 184), [41] (p. 13). Due to the confirmation of parts of this early timber camp construction at both the east and west side, its size has been narrowed down to 1.7 hectares. The erection of a stone camp in Timacum Minus, then, correlated with the installation and deployment of cohors II Aurelia Dardanorum during the reign of Marcus Aurelius, most probably in AD 169. For this developed stone form of the Timacum Minus camp, three major building phases have been confirmed by archaeological research since 1975 . Phase I comprises the initial erection of the stone camp as related to the initial encampment of cohors II Aurelia Dardanorum in the second half of the 2nd century AD. While the rounded towers on all four corners and the towers at the western and eastern gates already belong to this first construction period, further towers, which slightly protrude from the camp's northern, southern, and western walls to both in- and outside of the camp walls, have been assigned to a second building phase. The dating of this phase can only be narrowed down very generally, as the numerous grave stelae and dedicatory inscriptions from the surrounding civilian settlement, which were used as building material for the camp's rearrangement and tower construction, provide an overall terminus post quem of the mid-3rd century AD. Finally, the third phase displays reconstructions of the camp walls and enlargement of both angle and side towers sometime after phase II after the mid-3rd, probably during the 4th century AD $[17,28,36,37,40]$. In all three phases, however, the size of the stone camp of Timacum Minus resembled the early timber construction's 1.7 hectares. The camp's interior has only been investigated superficially so far (Figure 4). Apart from the major streets connecting the east and west gate and leading into the camp from the south towards its north wall [28] (p. 41), [42] (p. 275), a large building in the very middle of the camp has been excavated and addressed as a horreum [28] (pp. 50, 91-92), [36]. In addition, it is assumed that a Mars temple existed inside the camp. This assumption rests on several finds of dedicatory inscriptions to Mars, which were made both in the secondary contexts of the stone camp walls and throughout the village of Ravna and its surrounding farmland, but has not yet been confirmed archaeologically [28] (p. 42), [40] (pp. 53, 56), [41] (p. 17). Nevertheless, a remarkable feature was identified inside the camp's south-western wall. Here, a round structure unsuitable for dwelling or simple storage purposes was excavated. Various finds of slag inside and around the structure suggest that this was a type of ore processing facility [28] (p. 42), [32] (pp. 197-198), which directly links the site of Timacum Minus to the mining activity in its surroundings and may provide insights into systems of raw material transport, processing, and storage, as well as the involvement of the military in Timacum Minus in the regional mining industry. 


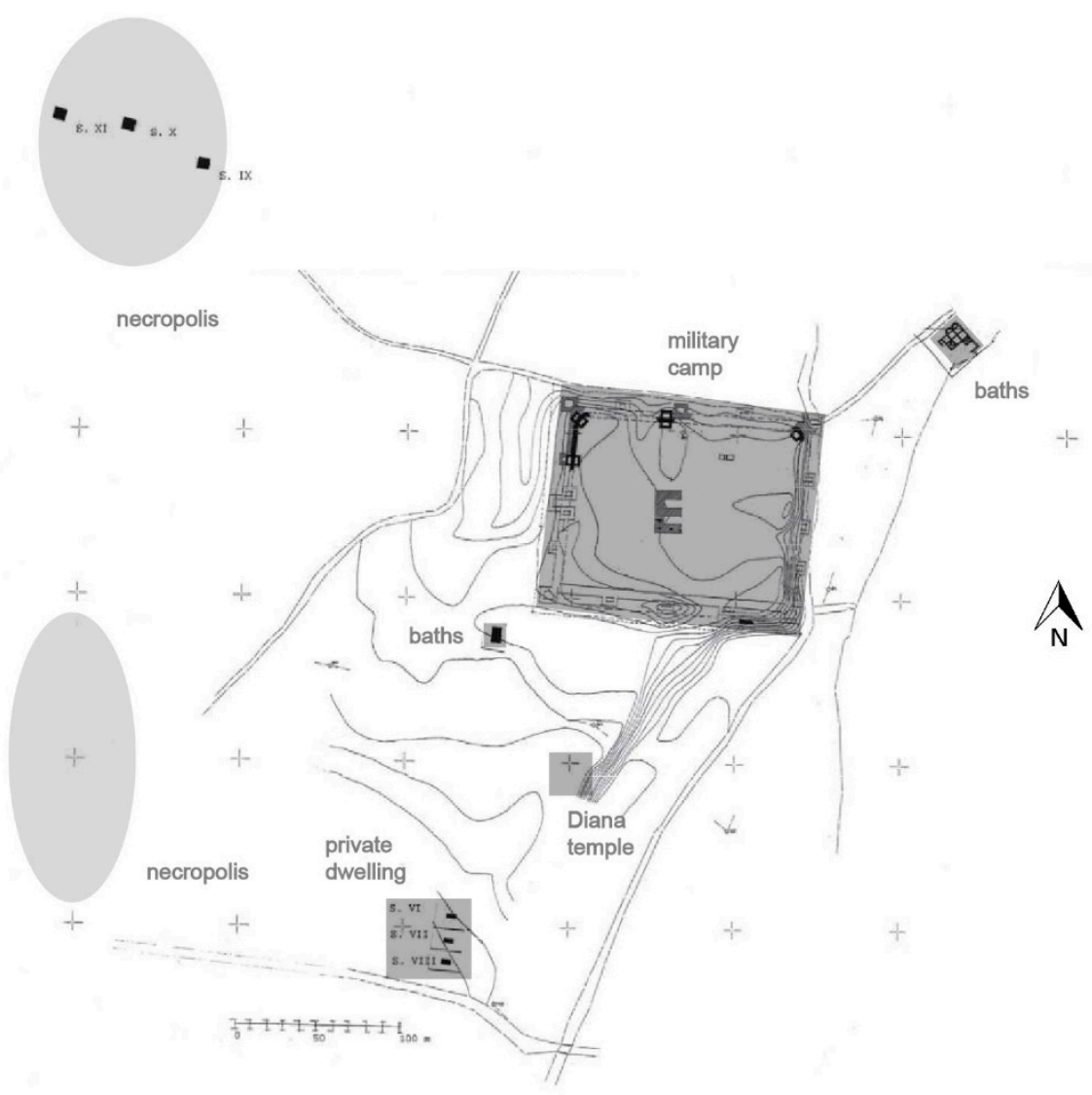

Figure 3. Overview of Timacum Minus (adapted from Petković and Ilijić, 2012, [43]).

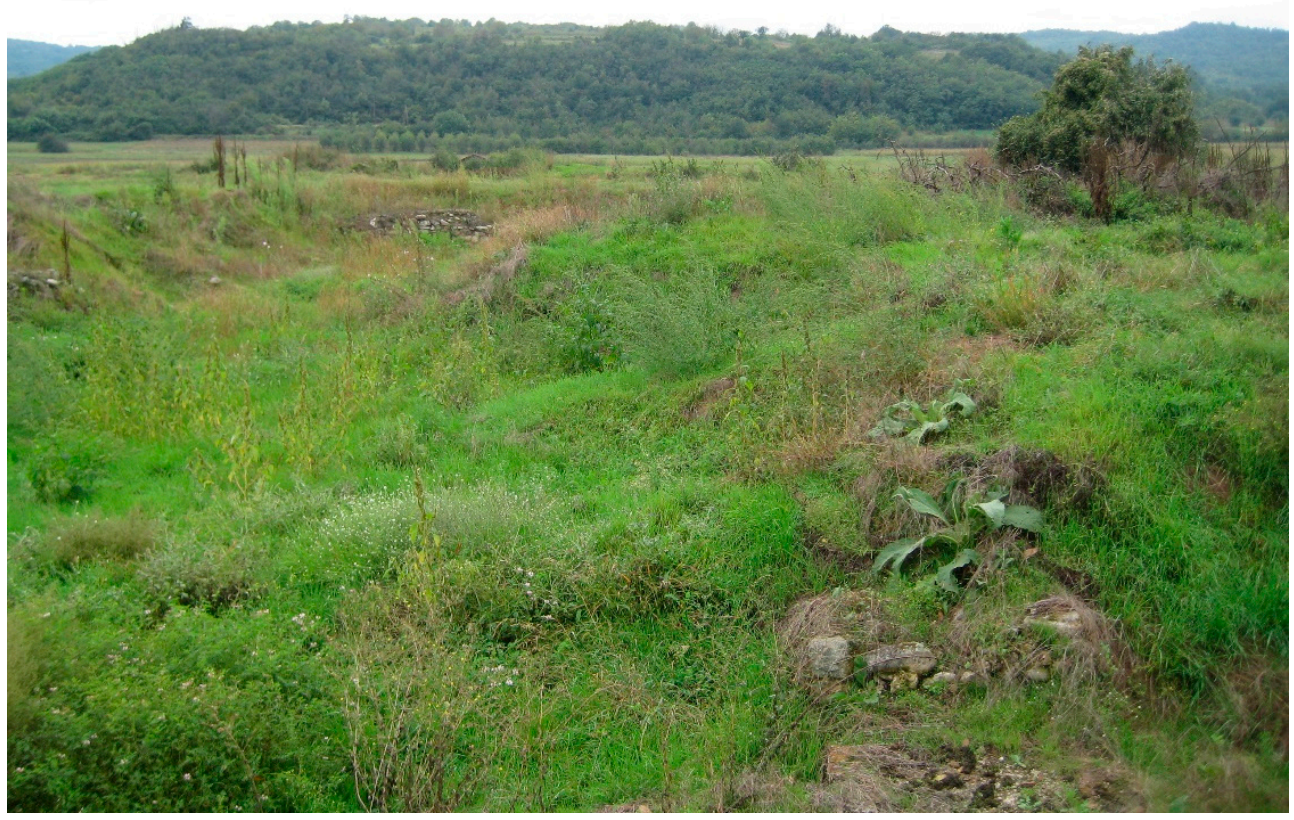

Figure 4. View from inside the military camp (horreum) towards the hill of Slog to the west of Timacum Minus (photo by L. Diers).

Due to the site conditions of Timacum Minus and Ravna as outlined above, the civilian settlement accompanying the military camp has only been investigated superficially so far. Nevertheless, the investigations onsite have generally confirmed the existence of this civilian settlement both to the north and south of the camp due to the identification of several buildings in these areas. First, sondages 
approximately $100 \mathrm{~m}$ south of the southern camp wall unearthed building remains, which date from the 2nd-3rd century AD. According to dedicatory inscriptions to Diana, which have been discovered in the direct vicinity, this building has been referred to as a Diana sanctuary [28] (pp. 42, 63-65, 71). Secondly, investigations 200-250 m southwest of the southern camp wall confirmed a structure from the late 3rd-4th century AD, which has been addressed as a private estate by the excavators [43] (pp. 153-178). Yet, layers underneath this building also attest to an inhabitation of the area in the 2nd-3rd and even in the 1st century AD already [43] (pp. 158-160, 168, 171). A third structure, which proved the civilian settlement's extent to the military camp's south, is the so-called south-western bath complex: Directly southwest of the south-western camp angle, a small structure has been partially investigated and, due to its hypocaust heating system and water pipes, addressed as a small bath complex [28] (pp. 40, 42), [41] (pp. 16-17). To the other, northern side of the camp, two structures indicate the spread and size of the Timacum Minus settlement. Around $100 \mathrm{~m}$ northeast of the camp's north-eastern corner, directly at the Beli Timok's left bank, a second bath complex was excavated (Figure 5). These northern baths consist of a large apodyterium, a central tepidarium, and various small niched rooms serving as caldaria and frigidaria and have been roughly dated to the 2nd-4th century AD [28] (pp. 40, 42), [37] (p. 123), [41] (pp. 16-17), [44] (p. 19), [45] (pp. 30-31). Furthermore, a mithraeum presumably existed north of the camp based on early finds of Mithraistic dedicatory inscriptions [28] (pp. 40, 42, 68-70). Archaeological investigations on the assumed spot of this Mithraeum have, however, not been conducted to date. Still, the north-eastern as well as the supposed south-western baths and the earliest occupation layers some $200 \mathrm{~m}$ southwest of the latter well attest to the settlement's spatial extent around the camp throughout the Principate.

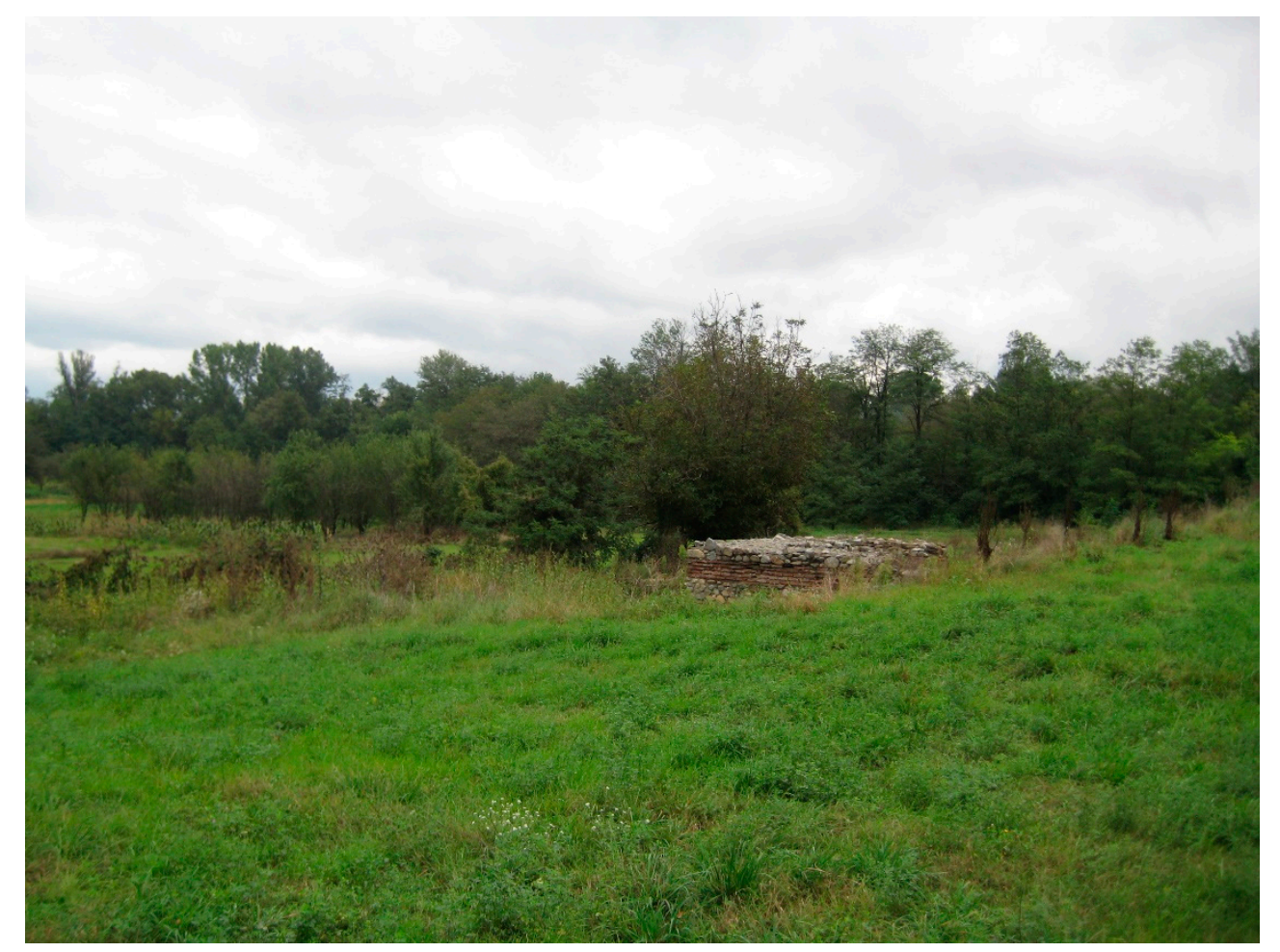

Figure 5. View from the western side of the north-eastern angle tower of the military camp of Timacum Minus - the area of the northern baths at the Beli Timok in the background (photo by L. Diers).

The civilian settlement of Timacum Minus is further delineated by its necropolises. Remains of burial grounds were found at several sites around Timacum Minus but especially to the west, southwest, and northwest of the military camp and settlement (Figures 3 and 6). Accordingly, agglomerations of graves have so far been investigated on the eastern slope of the Slog hill around 
$300 \mathrm{~m}$ southwest of the south-western camp corner, on the left bank of the Ropinski brook to the northwest of the camp, and between the Slog hill and the camp on the fields of Širina [28] (p. 42), [46]. Most of these graves, however, date from the 4th-5th century AD only. Single burials at all the mentioned sites also belong to the 1st-3rd century AD phases of the site [41] (p. 142); yet, this can only generally confirm that burial grounds were already in existence during the Principate. In fact, the reuse of grave stelae from the 1st-3rd century AD in the reconstruction works of the military camp in its phases II and III dislocated significant markers for the location and spread of the Principate-times burial grounds.

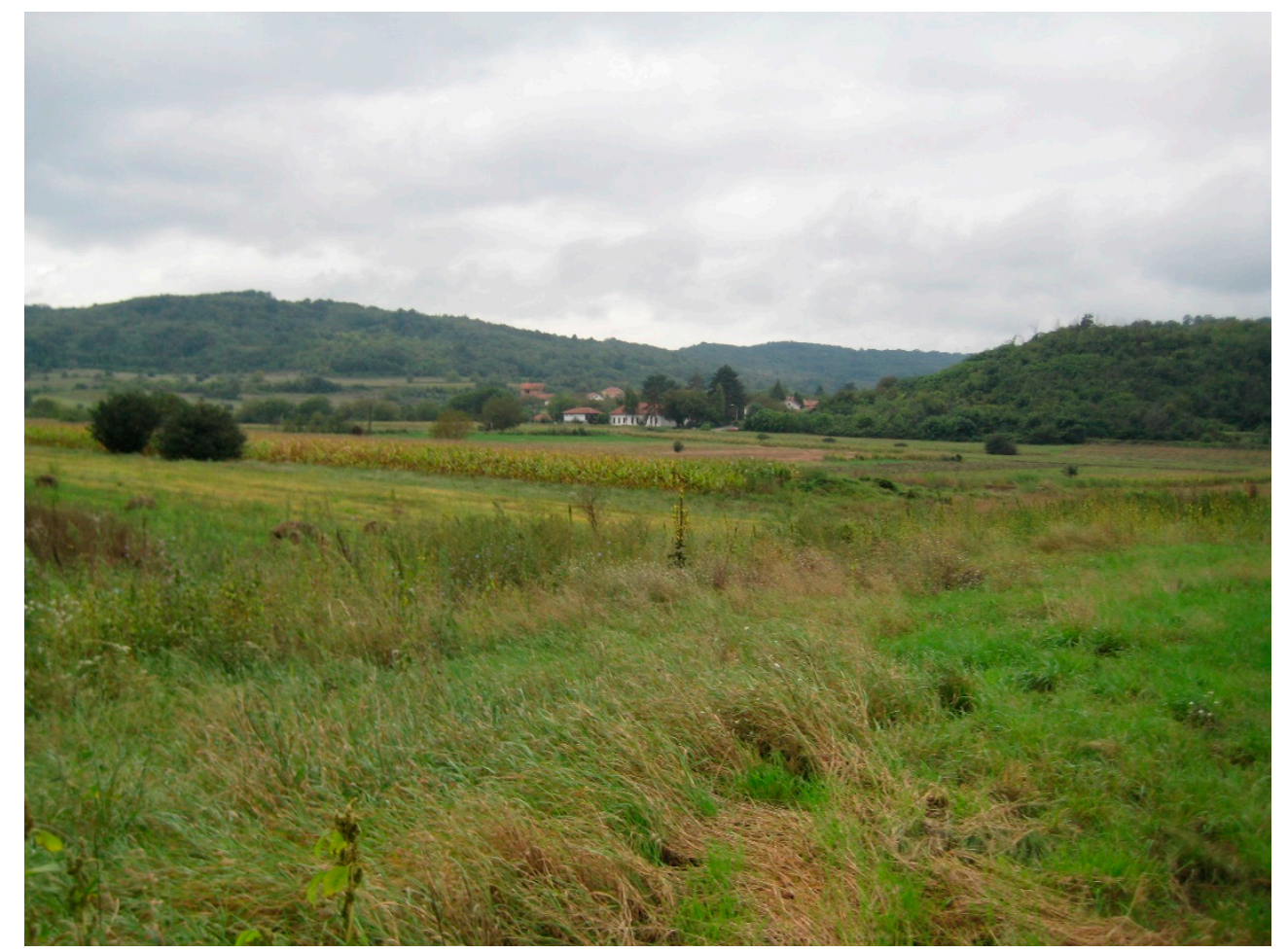

Figure 6. View from the military camp to the west and southwest: Civilian settlement and necropolises (photo by L. Diers).

Apart from the military camp and the actual settlement of Timacum Minus with its necropolises, three structures in the direct hinterland of the site further characterize the settlement and the outline of its relationship to mining activities in the wider vicinity. Firstly, a temple structure, which has been preliminarily dated to the 3rd century AD, was discovered underneath a church on the Sveta Trojica hill west of Timacum Minus and between today's Ravna and the neighboring village of Debelica [47] (p. 161). An inscription found onsite names the erection of a temple and, thus, confirms the identification of the building (IMS III/2, 99) [16] (p. 110), [28] (pp. 39, 43). Moreover, the inscription is of further significance, as it also names the donor of the temple, Cassius Achilleus. This name indicates that the temple had been commissioned by a freedman. Due to various finds of marble dedicatory slabs related to the Thracian rider and Jupiter, the temple is generally assigned to these deities. Clearly, there is no doubt that the temple at Sveta Trojica spatially and contextually belonged to Timacum Minus and was used by inhabitants of both camp and settlement. Secondly, the 19th century Balkan traveler Felix Kanitz reported of remains of a bridge over the Beli Timok north of the Timacum Minus military camp [44] (p. 19). Although it is not clear whether this bridge really was a Roman construction, it is likely that a river crossing facility was installed already during the Principate, as it would have greatly facilitated transport from the eastern mining areas around Timacum Minus and interregional traffic through the Timok valley. Eventually, a third interesting structure was identified on 
the hill of Podina to the northwest of Timacum Minus and north of the Slog hill. Here, traces of a small late antique fortification were found [48]. Although there are no hints at an earlier occupation of the site yet, it is likely that a watchtower or small fortification had already existed during the Principate, as such a structure would have overlooked the site of Timacum Minus as well as the Beli Timok and the fluvial plain around the site in general and, thus, would have safeguarded the transport of mining commodities and general traffic.

Although the date of Timacum Minus' initial emergence is not clearly indicated by the few archaeological features identified onsite, preliminary hints at the development of the site exist. The earliest layers underneath the private estate structure show that any kind of settlement activity around the earliest military camp already existed in the 1st century AD. Yet, there is a clear chronological emphasis of construction works on the 2nd and 3rd century AD, which indicates that large-scale settlement and urbanization processes in Timacum Minus were only set in motion after the onset of large-scale imperial mining ventures and the deployment of cohors II Aurelia Dardanorum. In terms of the size and extent of the settlement, the lack of archaeological data from the Principate-times burial grounds of Timacum Minus complicates an exact estimate. The location of the 4th-5th century AD necropolises, as well as the single Principate-times graves underneath them, however, generally limit the settlement territory to the west, northwest, and southwest, while in the east and north, the Beli Timok delineates the settlement space (Figure 3). In this way, the settlement of Timacum Minus can be narrowed down to an approximate size of 30 hectares, which is, for example, comparable to the mining site of so-called Municipium DD in southern Moesia Superior, today's northern Kosovo, which also did not have administrative status and mostly developed throughout the 2nd century AD [49].

\subsection{Administration and Centrality-Timacum Minus and Its Regional Context}

Assessing the character and status of the settlement has been one of the main foci and problems of research on Timacum Minus. While Sofija Petković calls Timacum Minus a "fortified administrative centre of the Upper Moesia mining region of the territoria metallorum" and an "urban settlement with public baths, villas, workshops, and temples" [46] (p. 87), Miroslava Mirković has addressed it as one of the "non-urban" settlements of Moesia [17] (p. 68-71). The central issue of the debate, which becomes apparent in these quotes, lies in the fact that there is no evidence-whether epigraphic or archaeological-for Timacum Minus' status. Given the high number of inscriptions found onsite, it is indeed highly likely that the lack of municipal or general official administrative references to the status of the settlement provides a representative picture. Andras Mócsy has therefore argued that Timacum Minus surely was no municipium and, thus, no regional centre [16] (p. 110), [26] (p. 225). However, these two statements really do not have to follow from each other. Petar Petrović remarked that the lack of a municipium in such a large and important region as the Timok valley indeed seemed astonishing [28] (p. 35). Hence, he opened a debate centered on a fragmentary inscription (IMS III/2, 26), which was found in a secondary use as building material for the phase II and III military camp walls of Timacum Minus and which names a decurio of a municipium [28] (pp. 79-80). Due to this inscription, Petrović did not want to completely eliminate the possibility that a so far unknown municipium existed at Timacum Minus. Still, he opted for an identification of the IMS III/2, 26-municipium with nearby Naissus or Viminacium [28] (p. 79). As the inscription is fragmentary only, it is very likely that it indeed named a decurio of one of these municipial settlements, who after his service came to live and/or be buried at Timacum Minus.

As the existence of a municipium in Timacum Minus can, thus, be eliminated, the settlement around the camp of cohors II Aurelia Dardanorum is commonly addressed as a vicus metalli [28] (p. 37), [31] (pp. 257-259). This characterization of Timacum Minus is further supported by comparing it to other mining settlements in Moesia. The mining territories of central Dardania around the settlements of Ulpiana and so-called Municipium DD in today's Kosovo had indeed been put under municipal administration and supervision. Yet, this did not result from the mining per se. Instead, 
it concerned the overall territorial administration of Roman settlement in the wider region of Dardania. So-called Municipium DD displays a similar situation as Timacum Minus. Large-scale imperial mining activities in the surroundings of the settlement started in the 2nd century AD, and inscriptions attest to administrative offices organizing this mining from Municipium DD [49]. Although it is perceived as a municipium, the settlement did not receive municipal rights but remained a vicus metalli with a centralized mining administration [19]. Nearby Ulpiana, which also developed due to the installation of an enclosed mining territory in its surroundings in the 2nd century AD, however, was granted municipal status shortly after its emergence. Yet, this needs to not be viewed in the context of the mining district and its administration; instead, it resulted from the lack of settlements and administrative bodies concerned with the overall administrative organization of the wider region of central Dardania [19]. In Timacum Minus, however, it seems that larger administrative bodies in the wider vicinity (the municipium of Naissus, the colonia of Ratiaria, and legio VII Claudia in Viminacium, which, together with its vexillations, governed a large area extending along the Danube Limes towards the Iron Gates and into the hinterland of the Danube Limes in terms of military territory) were enough to cater for local needs in efficient ways. In central Dardania such structures were not present in the vicinity, resulting in the creation of a regional center with municipal rights in Ulpiana. Here, an additional aspect to consider in terms of municipal rights granting in Moesia and its reasons is military recruitment. As the present evidence does not hint at a considerably dense pre-Roman and Principate-times indigenous inhabitation of the Timok valley [50], recruitment in the area might not have been a major aspect to facilitate. Moreover, it should also be taken into consideration that, given the lacking need for encompassing administration in the Timok valley, the fiscal character of the mining district around Timacum Minus might have been a reason for disabling a certain organizational autonomy in the settlement. Regarding the fiscal character of the mining district in the Timok valley, it is also interesting that the epigraphic record of Timacum Minus displays a relatively high number of Greek names [16] (p. 124), [28] (p. 46). On one hand, this might have resulted from the recruitment of cohors II Aurelia Dardanorum in Macedonia and Dardania. On the other hand, it might also be traced back to the imperial character of the mining territories around the settlement, which most probably resulted in the presence of imperial freedmen taking positions in the mining administration [28] (p. 47). This also fits the building inscription of the temple on the Sveta Trojica hill, which names a freedman as the temple donor. The mining industry and its administration obviously held certain economic and social potential for freedmen, which in general turned mining settlements into attractive agglomerative nodes and socially and economically appealing centers [19].

An interesting aspect to consider when thinking about the emergence and development of such a mining center in Timacum Minus clearly is its relationship with the other Roman settlements in the Timok valley. The Tabula Peutingeriana names Timacum Maius, Timacum Minus, and Conbustica as stations along the way from Naissus to Ratiaria [28] (pp. 23-30). Conbustica lies at the Bulgarian village of Kladorup, and Timacum Maius has only recently been identified at the site of Kalnica between the villages of Svrljig and Niševac in the southern Timok valley. At both Timacum Maius and Conbustica, military garrisons and civilian settlements with public facilities like baths and temples/shrines have been uncovered beside the road station [25,51-55]. Accordingly, both sites do not appear to be strikingly different from Timacum Minus. Yet, they were, and the aspect that differentiates Timacum Maius and Conbustica from Timacum Minus clearly is centrality, both in locational and in hierarchical terms. The distances from Naissus to Timacum Maius, Timacum Maius to Timacum Minus, Timacum Minus to Conbustica, and Conbustica to Ratiaria all range around $30-40 \mathrm{~km}$. This allowed for convenient stages of a day's journey when travelling the Timok valley road. Rapid military marches or travels in carriages or on horseback may have made it possible to pass Timacum Maius and Conbustica. Timacum Minus, however, always needed to be stopped at, as it was clearly not possible to travel the Naissus-Ratiaria road in one trip only. In addition, the mining administration and its economic, financial, and social prospects for office holders and investors of any kind clearly condensed in Timacum Minus, which would have made the settlement more attractive for settlers and turned it into a regional center. 


\section{Timacum Minus as a Central Place and Urban Mining Site}

In Roman urbanism, one of the basic conditions for towns has always been centrality [6] (p. 83). According to the economic function of towns as either consumers and/or market vessels [56,57], the principles of territorial administration, and the specific relationship between settlement and hinterland in the Roman Empire in general, Roman towns somehow always were central places. A certain amount of centrality is, thus, immanent to Roman settlement and urbanism. This is a very specific trait of ancient settlement patterns, and it may have contributed to the problems of grasping Roman urbanism beyond the consumer city, beyond center-periphery models, and beyond idealistic perceptions of urban evolution. Timacum Minus is a vibrant example of how to go beyond these aspects and basic central place theory, as it displays different levels of centrality. First, the settlement was geographically central, not only to its direct environment but also in simple, locational terms. Timacum Minus lay just amidst the Timok valley and the Timok valley road and at the spot where the fluvial landscape of the Timok tributaries coalesced. Although it is clear that centers do not necessarily relate to geographical or geometrical aspects, Timacum Minus may be viewed as the prime example for the 'law of location', as one might paraphrase Christaller's intention to search for logic patterns in site and settlement location [1] (p. 13). The settlement of Timacum Minus developed at its specific site because this site had a central location, where-given the local and regional circumstances during the Roman Principate, which especially becomes apparent in the Timok valley road and its landscape characteristics-a settlement actually had to emerge. The 1st century AD Timok valley road, which connected Naissus and Ratiaria and, thus, theoretically also the Adriatic, southern Moesia Superior, and western Moesia Inferior with the Danube, created a regional micro-landscape of centrality of its own. This landscape coalesced in Timacum Minus as a military post and settlement, which guarded private, political, economic, and military traffic along the Naissus-Ratiaria road together with Timacum Maius and Conbustica. According to these characteristics, one may call Timacum Minus a 'bridge' in the sense of Mark Granovetter [58] (p. 1364), [59]. In another way, this principle of site location has also been formulated by August Lösch. He stated that location and locational factors are mostly geographical facts. Yet, he also stated that what was made of these conditions in a specific regional and/or chronological context was open to be guided by different development factors [60] (p. 5). This is also very true for Timacum Minus. Despite the locational centrality, which resulted from the geographical and historical conditions of the Timok valley, the settlement also displays a second, much more crucial form of centrality-a hierarchical centrality. The natural resources the Timok valley and its surroundings offered and the large-scale mining industry, which was installed on the base of a fiscal mining district in the 2nd century AD, turned Timacum Minus into a regional center. Again, the site's central location amidst the Timok valley most probably was the primary factor for installing the Roman administrative bodies of the mining district just in Timacum Minus; yet, the organizational primacy of the site clearly made it hierarchically central in the time to follow. This trait is also the primary factor, which differentiates Timacum Minus from the other sites along the Naissus-Ratiaria road. Timacum Minus had characteristics Timacum Maius and Conbustica had not, and these characteristics were decisive for its urban development. Most importantly, however, both the locational and the hierarchical centrality of Timacum Minus were very much guided by local and regional conditions.

The significance of this also becomes apparent when looking at the longue durée. Evidence for mining in the Timok valley has also been found for the pre-Roman Iron Age and Late Antiquity; yet, the Timok valley in general was not densely settled during these periods. Timacum Minus itself only revealed singular scattered finds of pre-Roman material [50] (pp. 88-91, 134, 156-157), and the site was eventually abandoned in the 6th century AD. Today, the regional centers of eastern Serbia have moved to Knjaževac and Zaječar, and the village of Ravna merely has 300 inhabitants. In fact, mining is still conducted today but the mining centers now lie in Bor and Majdanpek north of the Timok valley [38]. Hence, the very specific historical, economic, and transport-related circumstances Timacum Minus was embedded in during the Roman Principate also created very specific conditions for site development, 
which have not reoccurred until today. Such temporarily singular developments surely speak for Timacum Minus as a regional center during the Roman Principate.

Timacum Minus' character as a regional center only during the Roman and late Roman period also speaks for its character as an urban settlement. Although the settlement was not distinctly large, did not have administrative status, and also did not have distinct potential for urban growth and monumentality as is indicated by its necropolises, which limit the settlement space, it clearly had urban character acted out on the levels of social practice and centrality. Timacum Minus had public buildings, which were partly privately funded by people who gained their economic and social status through the mining industry, and also was the only larger settlement in the wider region. Thus, it is the urban significance, which makes Timacum Minus stand out of the compound of Timok valley road stations, and this urban significance - again — resulted from the settlement's centralized administration and the economic and social potential the mining offered. This is, for example, made very clear by the development outline of the settlement: Although Timacum Minus already existed from Vespasian's reign onwards, all the archaeologically determined public buildings of Timacum Minus date from the mid-2nd-3rd century AD and, thus, only were erected after the mining industry and administration had been solidified in the Timok valley and Timacum Minus [19]. Problematically, the site conditions of Timacum Minus and the fragmentary state of archaeological research on the settlement and its surrounding mining sites so far hinder large-scale investigations of economic systems, the range of production and transport networks, the flow of people related to these networks, and-eventually-the relationship of all these aspects to the settlement of Timacum Minus. Still, it is very clear that, due to the mining, Timacum Minus had a specific relevance for regional and global markets and I argue that this had impact on local and regional urbanism. Timacum Minus shows that scale is not necessarily important, and that centrality does not necessarily relate to mathematic values. In fact, urbanism and centrality are both means of intensity and relation. In order to assess urbanity and urbanization, settlements should not only be quantified; instead, they should indeed be qualified. The qualifiers of urbanism in a local context, however, are not primarily administrative status and monumentality but centrality, which stems from geographical location and economic locational factors that, in turn, generate social agglomeration. Hence, one may say that Timacum Minus was a central place due to its embedment into a central landscape and a nucleated community in a sparsely settled area with a centralized regional administration, which is what eventually turned the site into an urban settlement of Roman Moesia.

\section{Conclusions}

The main objective of this paper was to question traditional approaches to urbanism. Accordingly, the paper aimed to show that predominant perceptions about urbanism are not suitable for the Roman province of Moesia and that brainstorming central place theory and centrality mechanisms can help not only to understand this but also to provide a different framework for the identification and characterization of urbanism and settlement patterns. When working on urban settlement in the Roman Empire, the most significant aspects to consider are systems of attractions and the energy and dynamics of settlement [61]. The ideology of urban form, which has long been questioned but is still used as a condition of Roman urbanism does not fit the reality of settlement dynamics throughout the Empire in general and in Moesia specifically. Urbanism studies, however, should not focus on implementing idealistic and idealized categorizations, but instead understand agglomeration. I argue that focusing on development factors for a settlement instead of administrative status and monumentality as the main trait of an urban site indeed facilitates the characterization of Roman urbanism and its development on local and regional levels. Centrality patterns and mechanisms as a result of these development factors, which go beyond the notion that settlements were central to their hinterland, further help to understand not only initial agglomeration but also the development of agglomeration. The principle of 'centralities', which I introduced in this paper using the mining settlement of Timacum Minus as a case study, clearly shows that in order to properly assess urbanity 
and urbanization in Moesia, the status of a site takes a back seat in favor of the decisive factors that made it become a site.

Although Christaller was in many ways too static with his central place theory and it has long become clear that central places need not be urban settlements, considering applications of central place theory on a theoretical level still is crucial for the settlement patterns of Moesia. Christaller explicitly stated that he did not intend to introduce a new definition of 'the urban' with his central place theory as this would lead to "considerable confusion" [1] (p. 25). I, however, want to do just that, and argue that using centrality as a criterion for urbanity and a condition for urbanization dissolves confusion about urbanism in Moesia rather than creates it.

Funding: This research was funded by the Austrian Academy of Sciences (Athens-Scholarship).

Acknowledgments: My special thanks go to Giorgos Papantoniou and Athanasios Vionis, who not only brilliantly organized the 'central places-un-central landscapes' panel at the AIAC 2018 in Cologne/Bonn but also provided the contributors with a well-defined theoretical framework for brainstorming central place theory and exceptional support during the publication process of this special issue of 'Land'. In addition, I want to thank the reviewers of this paper for their thoughtful comments and suggestions.

Conflicts of Interest: The author declares no conflict of interest.

\section{References}

1. Christaller, W. Die zentralen Orte von Süddeutschland. In Eine Ökonomisch-Geographische Untersuchung über die Gesetzmäßigkeit der Verbreitung und Entwicklung der Siedlungen mit Städtischen Funktionen, 2nd ed.; Wissenschaftliche Buchgesellschaft: Darmstadt, Germany, 1968.

2. Johnson, G.A. A test of the utility of Central Place Theory in archaeology. In Man, Settlement and Urbanism; Ucko, P., Tringham, R., Dimbleby, G.W., Eds.; Duckbacks: London, UK, 1972; pp. 769-785. ISBN 9780715605899.

3. Fulminante, F. Social network analysis and the emergence of central spaces: A case study from Central Italy (Latium Vetus). Bull. Antieke Beschaving 2012, 87, 27-53.

4. Müller, U. Networks of towns-Networks of periphery? Some relations between the north European medieval town and its hinterland. In Raumbildung durch Netzwerke? Der Ostseeraum Zwischen Wikingerzeit und Spätmittelalter aus Archäologischer Perspektive; Brather, S., Müller, U., Steuer, H., Eds.; Habelt: Bonn, Germany, 2012; pp. 55-78. ISBN 9783774937949.

5. Rivers, R.; Evans, T.S. What makes a site important? Centrality, gateways and gravity. In Networks in Archaeology: New Approaches to Regional Interaction; Knappett, C., Ed.; Oxford University Press: Oxford, UK; pp. 125-150. ISBN 9780199697090.

6. Martinez Jiménez, J.; Tejerizo Garcia, C. Central places in the post-Roman Mediterranean: Regional models for the Iberian Peninsula. J. Mediterr. Archaeol. 2015, 28, 81-103. [CrossRef]

7. Zanker, P. The city as symbol: Rome and the creation of an urban image. J. Roman Archaeol. Suppl. Ser. 2000, 38, 25-41.

8. Panzram, S. Monumentalisierung römischer Macht-Augusteische Stadtanlagen zwischen "Monotonisierung" und imitatio Urbis. In Fines Imperii-Imperium sine Fine? Römische Okkupations-und Grenzpolitik im Frühen Principat; Wiegels, R., Moosbauer, G., Kunst, C., Eds.; Verlag Marie Leidorf: Rahden, Germany, 2011; pp. 275-296. ISBN 9783896467355.

9. Lynch, K. A Theory of Good City Form; MIT Press: Cambridge, UK, 1981.

10. Laurence, R. Writing the Roman metropolis. In Roman Urbanism. Beyond the Consumer City; Parkins, H.M., Ed.; Routledge: London, UK, 1997; pp. 1-20.

11. Lomas, K. The idea of a city: Élite ideology and the evolution of urban form in Italy, 200 BC-AD 100. In Roman Urbanism. Beyond the Consumer City; Parkins, H.M., Ed.; Routledge: London, UK, 1997; pp. 21-41.

12. Alcock, S.E. Heroic myths, but not for our times. J. Roman Archaeol. Suppl. Ser. 2000, 38, 221-226.

13. Hanson, J.W. An Urban Geography of the Roman World, 100 BC to AD 300; Archaeopress: Oxford, UK, 2016; ISBN 9781784914721.

14. Vulpe, R. Colonies et Municipies de la Mesie Inférieure. Stud. Thracol. 1976, 1, 289-314. 
15. Dintchev, V. The municipia of the province of Moesia Inferior. In Limes XXII. Proceedings of the 22nd International Congress of Roman Frontier Studies, Ruse, Bulgaria, September 2012; Vagalinski, L., Ed.; NAIM: Sofia, Bulgaria, 2015; pp. 581-591.

16. Mócsy, A. Gesellschaft und Romanisation in der Römischen Provinz Moesia Superior; Akad. Kiadó: Budapest, Hungary, 1970.

17. Mirković, M. Moesia Superior. In Eine Provinz an der mittleren Donau; Zabern: Mainz am Rhein, Germany, 2007; ISBN 9783805337823.

18. Tačeva, M. Die Munizipalisierung in den Provinzen Moesia Superior und Moesia Inferior (Mitte des 2-Mitte des 3. Jhs.). In Römische Städte und Festungen an der Donau: Akten der Regionalen Konferenz, Beograd, 1-19 Oktober 2003; Mirković, M., Ed.; Filozofski fakultet: Belgrade, Serbia, 2005; pp. 211-217.

19. Diers, L. Local urbanism and global economy: The cases of Timacum Minus and Municipium Dardanorum/DD in Moesia Superior. Archaeol. Rev. Camb. 2018, 33, 58-81.

20. Revell, L. Roman Imperialism and Local Identities; University Press: Cambridge, UK, 2009; ISBN 9780521887304.

21. Diers, L. Urbanität und Urbanisierung. Überlegungen zu Siedlungscharakterisierung, urbaner Organisation und urbaner Lebenswelt in der römischen Provinz Moesia. In Akten des 16. Österreichischen Archäologentages am Institut für Klassische Archäologie der Universität Wien vom 25. bis 27. Februar 2016; Schörner, G., Meinecke, K., Eds.; Phoibos Verlag: Vienna, Austria, 2018; pp. 47-58. ISBN 9783851611823.

22. Mirković, M. Die Anfänge der Provinz Moesia. In Die römischen Provinzen—Begriff und Gründung; Piso, I., Ed.; Editura Mega: Cluj-Napoca, Romania, 2008; pp. 249-270. ISBN 9789731868813.

23. Petrović, V. Dardanija u Rimskim Itinerarima; SASA: Belgrade, Serbia, 2007; ISBN 9788671790567.

24. Petrović, V. Pre-Roman and Roman Dardania: Historical and geographical considerations. Balcanica 2007, 37, 7-23. [CrossRef]

25. Petrović, V.; Filipović, V.; Luka, K. The Roman road Naissus-Timacum Maius-Timacum Minus-Conbustica (Combustica) - Ratiaria. In Ratiaria Semper Floreat 1. Ratiaria and Its Territory; Ivanov, R., Ed.; Ratiaria semper floreat: Sofia, Bulgaria, 2014; pp. 97-142.

26. Mócsy, A. Pannonia and Upper Moesia: A History of the Middle Danube Provinces of the Roman Empire; Routledge \& Kegan Paul: London, UK, 1974.

27. Rummel, C. Lineare Verteidigung oder punktuelle Kontrolle-Die Nordgrenze der Balkanhalbinsel im 1. und 2. Jahrhundert n. Chr. In Kontaktzone Balkan. Beiträge des Internationalen Kolloquiums Die Donau-Balkan-Region als Kontaktzone Zwischen Ost-West und Nord-Süd“ vom 16-18 Mai 2012 in Frankfurt am Main; Bülow, G., Ed.; Habelt: Bonn, Germany, 2015; pp. 141-150. ISBN 9783774939837.

28. Petrović, P. Inscriptions de la Mésie Supérieure III/2. Timacum Minus et la Vallée du Timok; Filozofski fakultet: Belgrade, Serbia, 1995.

29. Dušanić, S. Iz istorije rimskog rudarstva u gornjoj meziji. Arheološki Vestnik 1977, 28, 163-179.

30. Dušanić, S. Army and Mining in Moesia Superior. In Kaiser, Heer und Gesellschaft in der Römischen Kaiserzeit. Gedenkschrift für Eric Birley; Alföldy, G., Ed.; Steiner: Stuttgart, Germany, 2000; pp. 343-363.

31. Dušanić, S. Roman mining in Illyricum-Historical aspects. In Dall'Adriatico al Danubio. L'Illirico Nell'età Greca e Romana; Urso, G., Ed.; ETS: Pisa, Italy, 2004; pp. 247-270.

32. Petrović, P. Der römische Bergbau in Ravna: Archäologische Notizen. In Ancient Mining and Metallurgy in Southeast Europe; Petrović, P., Ed.; Arheološki Institut: Belgrade, Serbia, 1995; pp. 195-202.

33. Tomović, M. Roman mines and mining in the mountains of Kosmaj. In Ancient Mining and Metallurgy in Southeast Europe; Petrović, P., Ed.; Arheološki Institut: Belgrade, Serbia, 1995; pp. 203-212.

34. Petrović, V.; Filipović, V. Newly-discovered traces of the Roman Naissus-Ratiaria road and the problem of locating two Timacum stations. Balcanica 2007, 38, 29-43. [CrossRef]

35. Hirt, A. Imperial Mines and Quarries in the Roman World: Organizational Aspects 27 BC-AD 235; University Press: Oxford, UK, 2010.

36. Petrović, P. Timacum Minus und die Kastelle im Timok-Tal. In Studien zu den Militärgrenzen Roms III. 13. Internationaler Limeskongreß Aalen 1983. Vorträge; Unz, C., Ed.; Theiss: Stuttgart, Germany, 1986; pp. 514-518.

37. Petrović, P. Rimljani na Timoku. In Arheologija Istočne Srbije; Lazić, M., Ed.; Filozofski Fakultet: Belgrade, Serbia, 1997; pp. 115-133.

38. Kondić, V. Bor and its surroundings in the Roman period. In Ancient Mining and Metallurgy in Southeast Europe; Petrović, P., Ed.; Arheološki Institut: Belgrade, Serbia, 1995; pp. 191-193. 
39. Mladenović, D. Urbanism and Settlement in the Roman Province of Moesia Superior; Archaeopress: Oxford, UK, 2012; ISBN 9781407309545.

40. Petrović, P. Stanice Timacum na putu Naissus-Ratiaria i antičko naselje kod sela Ravna. Starinar 1976, $26,43-56$.

41. Petković, S. Rimska i Srednjovekovna Nekropola u Ravni kod Knjaževca; Arheološki Institut: Belgrade, Serbia, 2005.

42. Petković, S.; Jovanović, S. Arheološka iskopavanja rimskog utvrđenja Timacum Minus kod sela Ravna, opština Knjaževac tokom 1997-1998. Godine-Sektor južne kapije. Starinar 2000, 50, 275-280.

43. Petković, S.; Ilijić, B. Prilog proučavanju rimskog naselja na lokalitetu Timacum Minus kod Knjaževca, istočna Srbija. Glasnik Srpskog Arheološkog Društva 2012, 28, 153-178.

44. Kanitz, F. Reise in Süd-Serbien und Nord-Bulgarien, Ausgeführt im Jahre 1864; Staatsdruckerei: Vienna, Austria, 1868.

45. Janković, M. The social role of Roman baths in the province of Moesia Superior. In The Archaeology of Water Supply; Zuchowska, M., Ed.; Archaeopress: Oxford, UK, 2012; pp. 27-39.

46. Petković, S.; Miladinović-Radmilović, N. Military graves from the late Roman necropolis at Slog in Ravna (Timacum Minus). Starinar 2014, 64, 87-130. [CrossRef]

47. Vulić, N. Antički spomenici naše zemlje. Spomenik Srpske Kraljevske Akademije 1909, 47, 152-161.

48. Miladinović-Radmilović, N.; Ilijić, B. Rezultati zaštitnih arheoloških iskopavanja lokalitetu Timacum Minus-Podina kod Knjaževca. Glasnik Srpskog Arheološkog Društva 2009, 25, 323-347.

49. Čerškov, E. Municipium DD kod Sočanice; Muzeja Kosova: Prishtina, Kosovo, 1970.

50. Stojić, M.; Ilijić, B. Arheološka Građa Srbije 6. Knjaževac. Kulturna Stratigrafija Praistorijskih Lokaliteta Knjaževačkog Kraja; Arheološki Institut: Belgrade, Serbia, 2011; ISBN 9788680093710.

51. Petrović, V.; Filipović, V. Locating the Timacum Maius station on the Roman road Lissus-Naissus-Ratiaria: New archaeological research. Balcanica 2008, 39, 47-58. [CrossRef]

52. Petrović, V.; Filipović, V. The Roman Station Timacum Maius (?). Evidence of Urbanization and Communications. Balcanica 2009, 40, 25-30. [CrossRef]

53. Petrović, V.; Filipović, V. Epigraphic and archaeological evidence contributing to identifying the location and character of Timacum Maius. Balcanica 2013, 44, 35-49. [CrossRef]

54. Petrović, V.; Filipović, V. The first cohort of Cretans-A Roman military unit at Timacum Maius. Balcanica 2015, 46, 33-39. [CrossRef]

55. Rummel, C.; Petrović, V.; Filipović, V. First geophysical survey of the Roman settlement at Niševac (Timacum Maius). Glasnik Srpskog Arheološkg Društva 2011, 27, 303-313.

56. Clarke, D. The Consumer City and the Postmodern City; Routledge: London, UK, 2003.

57. Van Oyen, A. The Roman city as articulated through terra sigillata. Oxf. J. Roman Archaeol. 2015, 34, $279-299$. [CrossRef]

58. Granovetter, M.S. The strength of weak ties. Am. J. Sociol. 1973, 78, 1360-1380. [CrossRef]

59. Collar, A.; Coward, F.; Brughmans, T.; Mills, B.J. Networks in Archaeology: Phenomena, abstraction, representation. J. Archaeol. Method Theory 2015, 22, 1-32. [CrossRef]

60. Lösch, A. The Economics of Location, 2nd ed.; Yale University Press: Newhaven, CT, USA, 1954.

61. Citter, C. Landscapes, settlements and sustainability. In Detecting and Understanding Historic Landscapes; Chavarría Arnau, A., Reynolds, A., Eds.; SAP Società Archeologica s.r.l.: Mantua, Italy, 2015; pp. $253-272$. ISBN 9788887115994.

(C) 2018 by the author. Licensee MDPI, Basel, Switzerland. This article is an open access article distributed under the terms and conditions of the Creative Commons Attribution (CC BY) license (http:/ / creativecommons.org/licenses/by/4.0/). 